\title{
PENTINGNYA PENDIDIKAN KEWARGANEGARAAN UNTUK MEMBANGUN KARAKTER BANGSA
}

\author{
Muhamad Fikri Zulfikar, Dinie Anggraeni Dewi \\ Pendidikan Guru Sekolah Dasar - Universitas Pendidikan Indonesia Kampus Cibiru \\ fzulfikar84@upi.edu, dinieanggraenidewi@upi.edu
}

\begin{abstract}
Citizenship education has been included in the curriculum, and learning is carried out in basic education at all levels. The function and role of civic education is to achieve the goals of national education. The aim of civic education itself is to make its citizens good citizens, because good citizens cannot directly support sustainable development in the country concerned. This research method adopts literature studies or literary research methods, which contain theoretical theories related to research problems, which collect data by studying books, documents, notes and reports related to problem solving, and it is hoped that education in Indonesia will enable students. prepared to become citizens. They are firm and consistent in defending the unitary state of the Unitary Republic of Indonesia, and the development of national characteristics is used as the main driver of state development. This means that every development effort must always be directed at aspects that have a positive impact on character building.
\end{abstract}

Key word : Education, Education citizenship, character. 


\begin{abstract}
Abstrak
Pendidikan kewarganegaraan telah dimasukkan ke dalam kurikulum, dan pembelajaran dilaksanakan di pendidikan dasar pada semua jenjang.Fungsi dan peran pendidikan kewarganegaraan adalah untuk mencapai tujuan pendidikan nasional. Tujuan dari pendidikan kewarganegaraan itu sendiri adalah untuk menjadikan warganya warga negara yang baik, karena warga negara yang baik tidak dapat secara langsung mendukung pembangunan berkelanjutan di negara terkait. Metode penelitian ini mengadopsi studi literatur atau metode penelitian sastra, yang memuat teori-teori teoritis yang berkaitan dengan masalah penelitian, yang mengumpulkan data dengan mempelajari buku, dokumen, catatan dan laporan yang berkaitan dengan pemecahan masalah, dan diharapkan pendidikan di Indonesia akan memampukan peserta didik. dipersiapkan untuk menjadi warga negara. Mereka tegas dan konsisten dalam mempertahankan negara kesatuan NKRI, dan pembangunan ciri-ciri bangsa dijadikan sebagai penggerak utama pembangunan negara. Artinya, setiap upaya pembangunan harus selalu diarahkan pada aspek yang berdampak positif bagi pembangunan karakter.
\end{abstract}

Kata kunci : Pendidikan, Pendidikan kewarganegaraan, karakter. 


\section{PENDAHULUAN}

Pendidikan kewarganegaraan merupakan bagian dari sistem pendidikan nasional yang utuh. Oleh karena itu, proses pendidikan kewarganegaraan dimasukan kedalam kurikulum dan pembelajaran pada semua jenjang Pendidikan sekolah dasar sampai ke universitas. fungsi dan peran Pendidikan kewarganegaraan itu untuk pencapaian tujuan pendidikan nasional. Untuk bisa memahami mata kuliah/ mata pelajaran pendidikan kewarganegaraan. maka dirancang, dikembangkan, dilaksanakan, dan dievaluasi dalam konteks tujuan pendidikan nasional. Karena itu semua merupakan landasan dan pola pikir Pendidikan kewarganegaraan.

Pendidikan kewarganegaraan ialah bentuk penggemblengan individu - individu agar mendukung dan memperkuat politik dinegaranya, sepanjang politik itu hasil dari kesepakatan. Tidak mungkin Pendidikan kewarganegaraan itu menentang atau berlawanan dengan politik yang ada di negara tersebut. Justru sebaliknya, Pendidikan kewarganegaraan mendukung dan memperkuat politiknya. Tujuan dari Pendidikan Kewarganegaraan itu sendiri adalah agar warganya menjadi warga negara yang baik, karena warga yang baik secara tidak langsung mendukung keberlangsungan negara yang bersangkutan.

Proses dari pendidikan Kewarganegaraan itu untuk memberdayakan dan membudayakan peserta didik dalam arti bahwa proses dan hasil pendidikan tersebut harus mampu memfasilitasi peserta didik untuk melakukan proses belajar untuk memperluas wawasan belajar untuk membangun kemampuan belaja ynag akan berguna untuk hidup dan berkehidupan yang akan dating dinegara tersebut. Pendidikan kewarganegaraan merupakan proses pendidikan untuk membangun keteladanan kemauan dan kemampuan mengembangkan kreatifitas yang mencerminkan jati diri bangsa yang syarat dengan nilai-nilai sosial kultural ke-indonesiaan. Pendidikan Kewarganegaraan (Civic Education) yang menempatkan secara proporsional aspek pendidikan, seperti: pengajaran sejarah pembentukan bangsa, nilai-nilai patriotisme dan cinta tanah air, semangat bela negara dan budi pekerti di dalam kurikulum pendidikan Indonesia.

\section{METODE}

Metode penelitian ini menggunakan metode studi pustaka atau penelitian sastra yaitu Berisi teori teori yang berkaitan dengan masalah penelitian. Studu pustaka atau penelitian sastra merupakan kegiatan wajib Dalam penelitian, khususnya penelitian akademik, tujuan utamanya adalah Pengembangan manfaat teoritis dan praktis, "Penelitian sastra merupakan suatu teknologi yang mengumpulkan data dengan mempelajari buku, dokumen, catatan, dan laporan yang berkaitan dengan pemecahan masalah.” Nazir (M. Nazir). 
Penelitian sastra adalah melakukan penelitian melalui penelitian dan membaca literatur yang berkaitan dengan objek penelitian. Oleh karena itu dengan menggunakan metode penelitian ini penulis dapat Mudah untuk memecahkan masalah yang akan dipelajari

\section{HASIL DAN PEMBAHASAN}

\section{A. Pengertian Pendidikan Kewarga- negaraan}

Pendidikan kewarganegaraan atau civic education merupakan program pendidikan yang mempunyai lingkungan interdisipliner yang didasarkan pada teori disiplin ilmu sosial, yaitu interdisipliner dan multidimensi, dan disiplin ilmu tersebut didasarkan pada disiplin ilmu politik yang terstruktur. Menurut National Council for Social Research (NCSS), kewarganegaraan adalah proses yang mencakup semua pengaruh positif dan bertujuan untuk membentuk pandangan warga tentang peran mereka dalam masyarakat. Sebagai program pendidikan, tujuan utama kewarganegaraan adalah membangun warga negara yang lebih baik berdasarkan kondisi, standar, dan standar ukuran (sebagaimana diatur dalam Pembukaan UUD 1945) (Cholisin, 2000: 1.7).

Dalam kesempatan yang sama, Nu'man Soemantri menjelaskan bahwa PKn merupakan program pendidikan dengan inti demokrasi politik yang berkembang dengan berkembangnya sumber-sumber ilmu lain, dan berdampak besar bagi pendidikan sekolah, masyarakat, dan orang tua. Agar berdampak positif, semua ini telah dilatih untuk mengembangkan keterampilan berpikir kritis siswa. Melakukan tindakan demokrasi secara analitis dan mempersiapkan kehidupan demokrasi yang sesuai dengan Pancasila dan UUD 1945 (Cholisin, 2000:1.7). Menurut Sunarso, dkk (2008:1), pendidikan kewarganegaraan merupakan bidang penelitian yang misinya mencerdaskan bangsa Indonesia melalui koridor "pendidikan berbasis nilai".

Konfigurasi atau sistemik PKn dibangun atas paradigma sebagai berikut:

Pertama, kurikulum kewarganegaraan dirancang sebagai tema pembelajaran yang bertujuan untuk mengembangkan potensi diri dan menjadi warga negara yang berakhlak mulia, cerdas, partisipatif, dan bertanggung jawab. Kedua, kewarganegaraan secara teoritis dirancang sebagai mata pelajaran yang meliputi aspek kognitif, emosional, dan psikomotorik yang menyatu dalam ruang lingkup pemikiran, nilai, konsep dan moral Pancasila, kewarganegaraan demokratis dan substansi negara, atau saling menembus dan membaur 
pertahanan. Ketiga, warga negara secara praktis dirancang sebagai tema pembelajaran, menekankan bahwa konten yang mengandung nilai-nilai dan pengalaman belajar berupa berbagai tingkah laku yang perlu direfleksikan dalam kehidupan seharihari, yaitu pembelajaran kehidupan warga negara dalam kehidupan bermasyarakat, ber-bangsa, dan bernegara. yang menguraikan pemikiran, nilai, konsep dan moral Pancasila, kewarganegaraan demokratis dan pertahanan kehidupan sosial nasional.

Oleh karena itu, jika fokusnya pada bidang penelitian, maka ideologi PKN yang sangat diperlukan adalah perilaku warga negara. Namun perlu disadari bahwa perilaku warga sangat terkait dengan lingkungan, sehingga bidang penelitian ini adalah lingkungan tempat tinggal dan keberadaan warga negara. Situasi perilaku yang dimaksud adalah perilaku yang ditunjukkan individu dalam keadaan atau kondisi tertentu, misalnya karena individu tersebut adalah anggota keluarga, bagaimana individu tersebut berperilaku sebagai warga negara di rumah? Bagaimana individu bermain, berpikir, bekerja dan bertindak sebagai anggota kelas di sekolah karena mereka adalah anggota sekolah. Beginilah dia berperilaku dalam masyarakat sebagai anggota demokrasi atau masyarakat sipil, apakah dia anggota partai politik atau anggota organisasi sosial?

\section{B. Tujuan Pendidikan Kewarga- negaraan}

Secara keseluruhan pendidikan kewarganegaraan bertujuan untuk mewujudkan nilai-nilai dan akhlak setiap warga negara dalam Pancasila, nilai dan norma Undang-Undang Dasar Negara Republik Indonesia Tahun 1945, dan komitmen Bhineka Tunggal Ika, serta komitmen pada persatuan Republik Indonesia. Oleh karena itu, secara sadar dan sistematis, sesuai dengan perkembangan dan psikologi serta latar belakang kehidupannya, mendorong siswa untuk mempelajari seluruh kehidupan demokrasi, yaitu belajar demokrasi, belajar dalam iklim, dan menegakkan demokrasi melalui pembelajaran dan Menurut kurikulum Center yang dikutip oleh Sunarso, dkk (2008: 11), PKn bertujuan untuk menyediakan kemampuan sebagai berikut:

a. Pikirkan secara kritis, rasional dan kreatif tentang masalah kewarganegaraan.

b. Berkualitas tinggi, berpartisipasi secara bertanggung jawab, dan bertindak bijak dalam kegiatan kemasyarakatan, nasional, dan kenegaraan.

c. Berkembang secara positif dan demokratis, membentuk diri Anda 
dengan karakter bangsa Indonesia, dan memungkinkan mereka untuk hidup bersama negara lain.

d. Menggunakan teknologi informasi dan komunikasi untuk berinteraksi langsung atau tidak langsung dengan negara lain di dunia.

Menurut Ahmad Sanusi, Cholisin (2000: 1.17) mengemukakan bahwa biasanya tujuan utama pendidikan kewarganegaraan adalah sebagai berikut:

a. Hidup kita dijamin oleh Konstitusi.

b. Menurut pembudidayaan nasional yang diatur oleh konstitusi.

c. Tingkatkan kesadaran sipil melalui pendidikan dan pertukaran politik.

d. Mendidik warga negara yang bertanggung jawab.

e. Latihan demokrasi.

f. Berpartisipasi aktif dalam urusan publik.

g. Sekolah berfungsi sebagai laboratorium demokrasi.

h. Prosedur pengambilan keputusan.

i. Latihan kepemimpinan.

j. Pengawasan demokratis terhadap badan eksekutif dan legislatif.

k. Mempromosikan pemahaman dan kerjasama internasional.

\section{Landasan Pendidikan Kewarga- negaraan}

Undang-Undang Dasar 1945 yang menjadi landasan konstitusional pada awal alinea keempat menjadi landasan teori bagi tujuan bernegara. Salah satu tujuan bernegara dapat diperjelas dari pernyataan "pendidikan kehidupan bangsa". Jika dilihat, ketiga kata ini memiliki arti yang dalam. Kehidupan pendidikan di suatu negara mengandung informasi tentang pentingnya pendidikan bagi semua anak di negara tersebut. Dalam kehidupan warga negara, pernyataan ini menyampaikan informasi kepada penyelenggara negara dan setiap orang, sehingga memungkinkan mereka memiliki kemampuan berpikir, bertindak, dan berperilaku dalam proses penyelesaian masalah dan pengambilan keputusan nasional dan sosial.

Undang-Undang Nomor 20 Tahun 2003 tentang penggunaan sistem pendidikan nasional sebagai dasar dan informasi bagi dunia usaha yang berkaitan dengan pendidikan kewarganegaraan. Dalam Pasal 3 ayat (2) tentang fungsi dan tujuan negara disebutkan bahwa peran pendidikan nasional adalah untuk mengembangkan dan membentuk karakter dan peradaban bangsa yang bermartabat dalam kehidupan para intelektual negara, yang bertujuan untuk membangun bangsa. negara. Orang yang berakhlak mulia, sehat, berilmu, cakap, kreatif, mandiri, demokratis, dan bertanggung jawab berpotensi menjadi manusia yang 
beriman dan bertakwa kepada Tuhan Yang Maha Esa.

"Undang-Undang Sistem Pendidikan Nasional" tentang integritas pendidikan kewarganegaraan sebagai mata kuliah wajib bagi pendidikan dasar, menengah, dan tinggi menunjukkan bahwa disiplin ilmu ini mempunyai posisi yang strategis dalam pencapaian tujuan pendidikan nasional negara. Arah pengembangannya harus fokus pada menjadikan siswa agar menjadi orang Indonesia yang memiliki rasa kebangsaan dan cinta tanah air.

Perkembangan disiplin ilmu PKn di Indonesia memiliki sejarah panjang dalam pembinaan warga negara berdasarkan hak dan kewajibannya. Sejak didirikan pada tahun 1957, nama dan program warga telah berubah selama enam puluh tahun terakhir.

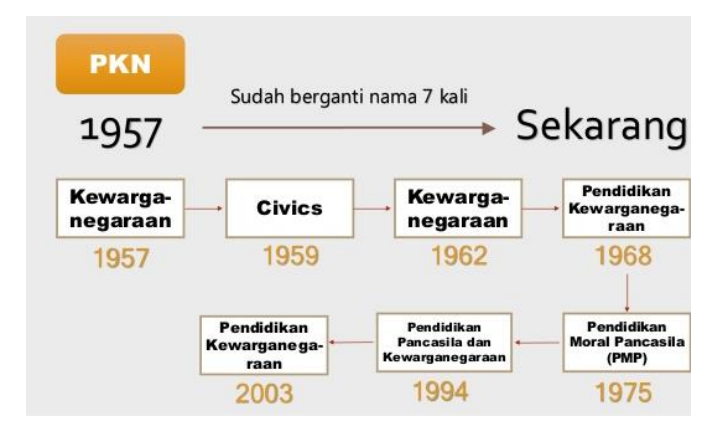

\section{Gambar 1 Nama PKN dari 1957 sampai sekarang}

Kata Nuh: "Tidak ada kurikulum yang kekal. Kurikulum berubah karena perubahan jaman, bukan karena kualitas kurikulum saat ini. Benar pada masanya. Tetapi jaman sedang berubah, dan kita juga harus berubah" (Santoso dkk., 2015, hlm.86). Pengembangan dan evaluasi kurikulum pendidikan kewarganegaraan Indonesia memiliki keunikan tersendiri dalam setiap perubahan isinya, sehingga tidak ada kurikulum yang abadi. Somantri (1969, p. 7) menjelaskan bahwa mata pelajaran kewarganegaraan atau kewarganegaraan pada dasarnya terdiri dari pengalaman belajar pada saat itu, pengalaman belajar tersebut berasal dari sejarah, geografi, ekonomi dan politik, pidato presiden, deklarasi hak asasi manusia dan pengetahuan tentang Persatuan. Bangsa”.

Pendidikan di Indonesia diharapkan dapat mempersiapkan peserta didik menjadi warga negara yang tegas dan konsisten dalam membela negara kesatuan Republik Indonesia. Hakikat negara kesatuan Republik Indonesia adalah negara-bangsa modern. Negarabangsa modern adalah negara yang dilandasi oleh semangat kebangsaan atau nasionalisme, artinya, meskipun warga negara tersebut memiliki keyakinan agama yang berbeda, suatu masyarakat bertekad untuk membangun masa depan, ras, ras, atau kelompok yang sama dalam satu kesatuan. negara. (Sekretariat Nasional Republik Indonesia, 1998).

Komitmen yang tegas dan konsisten terhadap prinsip dan semangat ke- 
bangsaan dalam bermasyarakat, berbangsa, dan berbangsa yang berlandaskan Pancasila dan UndangUndang Dasar Negara Republik Indonesia perlu terus disampaikan guna memperdalam pemahaman tentang Negara Kesatuan Republik Indonesia. Secara historis, negara Indonesia diciptakan sebagai negara kesatuan Republik Indonesia. Negara Kesatuan Republik Indonesia adalah bangsa kedaulatan rakyat. Landasannya adalah satu-satunya manusia yang ketuhanan, adil dan beradab. Persatuan dan masyarakat Indonesia dipimpin oleh kearifan dan kearifan dalam musyawarah yang representatif, dan telah mewujudkan masyarakat semua. Rakyat indonesia keadilan. (Pembukaan Undang-Undang Dasar Negara Republik Indonesia Tahun 1945).

Dalam konteks pembentukan karakter dan negara seperti ini, pendidikan kewarganegaraan memiliki fungsi dan peran yang sangat penting. Pendidikan kewarganegaraan merupakan pembangunan pendidikan karakter yang sistematis dan sistematis, yang tidak terlepas dari kerangka kebijakan pembangunan nasional, pembangunan nasional, dan pembangunan karakter.

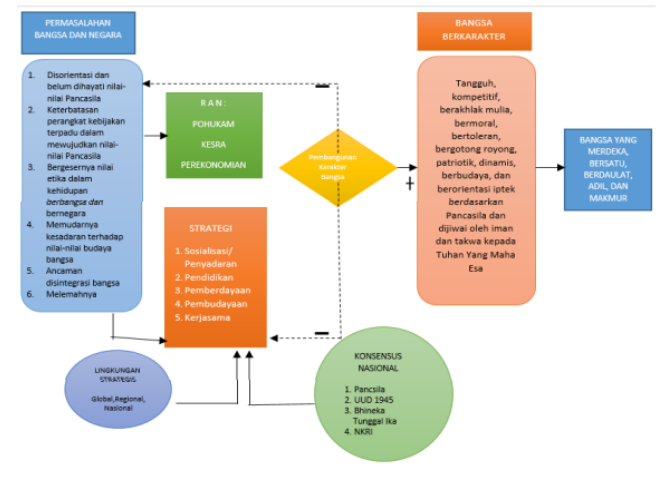

Gambar 2 Kerangka Kebijakan Nasional Pembangunan Bangsa dan Karakter (Menkokesra : 2010)

Selama 72 tahun kemerdekaan, Indonesia telah mengalami berbagai peristiwa yang mengancam keutuhan negara. Oleh karena itu, perlu ditanamkan pemahaman yang mendalam dan komitmen yang tegas dan konsisten terhadap prinsip-prinsip semangat kebangsaan dalam kehidupan bermasyarakat, berbangsa, dan berbangsa yang berlandaskan Pancasra dan Undang-Undang Dasar Negara Republik Indonesia di seluruh bagian konstituen bangsa Indonesia, khususnya sebagai penerus bangsa. bangsa, generasi muda.

Kedepannya, Indonesia akan menikmati kehidupan demokrasi yang lebih baik, dalam arti sistem pemerintahan akan lebih terlindungi dalam kehidupan bermasyarakat, berbangsa, dan bernegara, warga berhak menjalankan prinsip-prinsip demokrasi. Demi kemuliaan bangsa dan negara Indonesia, kehidupan demokrasi keluarga, sekolah, masyarakat, pe- 
merintah dan lembaga swadaya masyarakat dalam kehidupan seharihari perlu diakui, digagas, diinternalisasikan dan diimplementasikan. Demokrasi suatu negara hanya dapat berkembang di bawah pengawasan warga negara demokratis. Warga negara demokratis tidak hanya menikmati hak atas kebebasan pribadi, tetapi juga harus berbagi tanggung jawab dengan orang lain untuk membentuk masa depan yang cerah. Padahal, kehidupan demokrasi adalah cita-cita yang diwujudkan dan dianugerahkan ketika para pendiri negara dan negara pertama kali membahas dan merumuskan Pancasila dan UUD 1945.

Pembangunan karakter bangsa dijadikan sebagai arus utama pembangunan nasional. Artinya setiap upaya pembangunan harus selalu diarahkan pada aspek yang berdampak positif bagi pembangunan karakter. Padahal, hal tersebut secara konstitusional tercermin dalam misi pembangunan nasional. Menurut "Rencana Pembangunan Jangka Panjang Nasional 2005-2025" (dalam Zubaidi, 2011: 7), pendidikan karakter diposisikan sebagai tugas pertama dari delapan tugas untuk mewujudkan visi pembangunan nasional. Kuat, berdaya saing, berakhlak mulia, dan bermoral berlandaskan Pancasila yang merinci ciri dan perilaku masyarakat dan masyarakat Indonesia, keragaman bangsa dan bangsa Indonesia, kepercayaan dan rasa takjub akan kemahakuasaan, kebaikan, toleransi, dan kerjasama, Dengan patriotisme, perkembangan dinamis, dan berorientasi pada iptek

Peran warga negara sebagai garda terdepan pendidikan karakter sudah jelas, harus mengintegrasikan nilainilai karakter dalam kegiatan belajar mengajar, karena hal ini secara jelas dituangkan dalam tujuan belajar warga yang dijabarkan dalam (Darmadi, 2010: 52), yaitu: pembinaan Moralitas yang diharapkan dapat diwujudkan dalam kehidupan sehari-hari adalah perbuatan menyebarkan iman dan taqwa kepada Tuhan Yang Maha Esa dalam masyarakat yang terdiri dari berbagai kelompok agama, perbuatan manusiawi dalam keadilan dan peradaban, serta diversifikasi perbuatan untuk mendukung persatuan bangsa dalam masyarakat. kepentingan masyarakat mendukung perilaku masyarakat yang mengedepankan kepentingan bersama di atas kepentingan individu dan kelompok, sehingga dapat mewujudkan perbedaan pemikiran, pendapatan atau kepentingan melalui musyawarah mufakat, dan mendukung upaya pencapaian keadilan sosial bagi seluruh rakyat Indonesia. orang. 
Berdasarkan tujuan tersebut dapat dipahami sebagai pembelajaran kewarganegaraan adalah pembelajaran yang isi pembelajarannya sarat dengan nilai individu. Namun permasalahan yang peneliti temukan di bidang ini adalah bahwa pembelajaran dan praktik pendidikan kewarganegaraan yang dilaksanakan di dalam kelas saat ini terbatas pada pendidikan yang bertujuan untuk mencapai tujuan kognitif atau pengetahuan. Pada saat yang sama, secara emosional, hal-hal yang berkaitan dengan proses pembentukan karakter / sikap siswa seringkali terabaikan. Pandangan Suwarma (Budimansyah, 2012: 450) juga memperkuat pandangan ini, yaitu: siswa dalam keadaan pasif dapat menerima status mata kuliah setiap saat, pengetahuan lebih kuat dari sikap dan keterampilan, dan penggunaan metode dibatasi pada tidak menyenangkan. situasi belajar dan satu arah. Oleh karena itu, perlu diawali dengan perencanaan, pelaksanaan, dan evaluasi untuk meningkatkan pembelajaran PKn dalam pengembangan karakter peserta didik. Kita harus mampu merencanakan, melaksanakan, dan mengevaluasi untuk menginternalisasi nilai-nilai karakter yang ada, karena menumbuhkan nilai-nilai karakter tidak hanya membutuhkan pengajaran tetapi juga pengembangan.
Seperti yang dikatakan Hermann dalam (Budimansyah, 2010: 68), "nilai bukanlah dipelajari atau diajarkan, itu dipelajari”. Hal ini agar sebagai pendidik, kita dapat membina anakanak yang cerdas sekaligus individual.

Pembentukan kecerdasan emosional yang mengarah pada sikap/peran individu dapat dicapai melalui pendidikan peran. Banyak ahli yang mengetahui sesuatu tentang pendidikan karakter. Zubaedi (2012: 15) mengemukakan bahwa pendidikan moral merupakan suatu upaya yang disengaja (disadari) untuk mencapai kebajikan, yaitu memiliki kualitas manusia yang baik secara obyektif, yang tidak hanya bermanfaat bagi individu, tetapi juga bagi seluruh masyarakat. Selain itu, David Elkind dan Freddy Sweed mengemukakan dalam (Zubaedi, 2012: 15) bahwa pendidikan karakter adalah upaya yang disengaja (untuk secara sadar membantu orang memahami, peduli dan menerapkan nilai-nilai inti moral. Bila kita mempertimbangkan jenis karakter yang kita inginkan Anak, Anak-anak, tentu saja, kita mengharapkan mereka untuk dapat menilai apa kebenaran itu, benar-benar peduli dengan kebenaran, dan bahkan dalam menghadapi tekanan eksternal dan upaya internal, kita dapat menghitung apa yang mereka anggap sebagai kebenaran. 
Mata pelajaran kewarganegaraan sebenarnya merupakan salah satu mata pelajaran yang kaya akan nilai karakter. Kewarganegaraan merupakan salah satu bidang utama pembelajaran karakter. Oleh karena itu, tujuan karakter yang ditetapkan dalam PKn sebenarnya adalah pengaruh pengajaran, bukan sekedar pengaruh pendampingan.

Hal ini sejalan dengan pedoman pengembangan silabus dengan ciri khas Kementerian Pendidikan Nasional yang dikutip dalam Gunawan (2012: 226), pedoman tersebut bertujuan untuk memajukan pembelajaran dan membantu siswa dalam mengembangkan karakter. tugas-tugas berikut harus diselesaikan:

a. Menambah dan/atau memodifikasi kegiatan pembelajaran sehingga memuat kegiatan pembelajaran yang dapat membentuk nilai karakter yang diinginkan.

b. Menambah dan/atau memodifikasi teknik evaluasi sehingga teknik evaluasi untuk pengembangan karakter dapat dikembangkan dan / atau diukur.

\section{PENUTUP}

\section{A. Kesimpulan}

Pendidikan kewarganegaraan merupakan salah satu pilar pembentukan karakter dan jati diri bangsa, artinya pendidikan kewarganegaraan mendidik warga negara menjadi warga negara yang baik (good citizen) dan smart citizen (warga negara yang cerdas) guna menghadapi perkembangan dunia di era persaingan. Pendidikan karakter dalam pembelajaran kewarganegaraan merupakan solusi yang dapat merevitalisasi peran warga negara sebagai disiplin ilmu yang merupakan ladang unggulan dalam pembinaan karakter peserta didik. Kewarganegaraan merupakan mata pelajaran kewarganegaraan, dan muatan materinya memiliki nilai karakter yang kaya, yang selanjutnya akan membantu mengintegrasikan konsep pendidikan karakter. Pengembangan karakter siswa tidak hanya dapat dikembangkan melalui muatan materi kewarganegaraan, tetapi juga secara tidak langsung melalui berbagai tahapan kegiatan pembelajaran. Selain itu, pengembangan karakter siswa juga dapat didukung dengan penggunaan metode, media dan sumber belajar.

\section{B. Saran}

Pendidikan karakter perlu dipersiapkan dalam pembelajaran mulai dari tahap perencanaan, pelaksanaan dan evaluasi pembelajaran. Pada tahap perencanaan harus disiapkan materi, metode, media, sumber belajar, tahapan kegiatan pembelajaran dan evaluasi untuk mendukung pelaksanaan pendidikan karakter. Komponen komponen pembelajaran secara tidak langsung dapat membantu 
pengembangan tipe karakter yang ditentukan.

\section{DAFTAR PUSTAKA}

Akbal, M. (2017, October). Pendidikan Kewarganegaraan dalam pembangunan karakter bangsa. In Prosiding Seminar Nasional Himpunan Sarjana Ilmu-Ilmu Sosial (Vol. 2, pp. 485-493).

Budimansyah, D. 2008. "Revitalisasi Pembelajaran Pendidikan Kewarganegaraan melalui Praktik Belajar Kewarganegaraan (Project Citizen)" dalam Acta Civicus Vol. 1. Nomor 2, April 2008.

Budimansyah, D. 2009. Inovasi Pembelajaran Project Citizen. Bandung: Program Studi Pendidikan Kewarganegaraan SPs Universitas Pendidikan Indonesia.

Budimansyah, D. 2010. Penguatan Pendidikan Kewarganegaraan untuk Membangun Karakter Bangsa. Bandung: Widya Aksara Press.

Budimansyah, D., Syaifullah, S. 2006. Pendidikan Nilai-Nilai Moral dalam Dimensi Pendidikan Kewarganegaraan. Laboratarium Pendidikan Kewarganegaraan FPIPS UPI.

Cholisin. 2011. Pengembangan Karakter Dalam Materi Pembelajaran Pkn. Yogyakarta: Universitas Negeri Yogyakarta.

Dianti, P. (2014). Integrasi Pendidikan Karakter dalam pembelajaran Pendidikan Kewarganegaraan untuk mengembangkan karakter siswa. Jurnal Pendidikan Ilmu Sosial, 23(1).

Gunawan, H. 2012. Pendidikan Karakter (Konsep dan Implementasi). Bandung: Alfabeta.
Kurniawan, M. I. (2013). Integrasi Pendidikan Karakter Ke Dalam Pembelajaran Kewarganegaraan Di Sekolah Dasar. Jurnal Pemikiran dan Pengembangan Sekolah Dasar (JP2SD), 1(1), 37-45.

Saputra, E. (2016). Peranan Metode Diskusi Dalam Pembentukan Karakter Mahasiswa Melalui Mata Kuliah Pendidikan Kewarganegaraan (PKn). Tingkap, 11(1), 26-40.

Somantri, Nu'man. (2001). Menggagas Pembaharuan Pendidikan IPS. Dedi Supriadi \& Rohmat Mulyana (ed). Bandung: PPS-FPIPS UPI.

Sukardi. (2013). Metodologi Penelitian Pendidikan Kompetensi dan Praktiknya. Jakarata: PT Bumi Aksara.

Suwito, A. (2012). Integrasi Nilai Pendidikan Karakter ke dalam Mata Pelajaran Pendidikan Kewarganegaraan di Sekolah Melalui RPP. CIVIS, 2(2/Juli).

Undang-Undang Republik Indonesia Nomor 20 Tahun 2003 Tentang Sistem Pendidikan Nasional. Depdiknas, Jakarta.

Wibowo, A. P., \& Wahono, M. (2017). Pendidikan Kewarganegaraan: usaha konkret memperkuat multikulturalisme di Indonesia. Jurnal Civics: Media Kajian Kewarganegaraan, 14(2), 196-205.

Winarno. (2020). Paradigma baru Pendidikan Kewarganegaraan edisi keempat. Jakarta Timur: PT Bumi Aksara.

Gambar 3 Nama PKN dari 1957 sampai sekarang.

Gambar 4 Kerangka Kebijakan Nasional Pembangunan Bangsa dan Karakter (Menkokesra : 2010). 